\title{
The Crystal Structures in Hydrogen Absorption Reactions of REMgNi 4 -Based Alloys (RE: Rare-Earth Metals)
}

\author{
Toyoto Sato ${ }^{1, *(1)}$ and Shin-ichi Orimo ${ }^{2,3}$ \\ 1 Department of Engineering Science and Mechanics, College of Engineering, Shibaura Institute of Technology, \\ Tokyo 135-8548, Japan \\ 2 Advanced Institute for Materials Research (WPI-AIMR), Tohoku University, Sendai 980-8577, Japan; \\ shin-ichi.orimo.a6@tohoku.ac.jp \\ 3 Institute for Materials Research, Tohoku University, Sendai 980-8577, Japan \\ * Correspondence: toyoto@shibaura-it.ac.jp
}

check for

updates

Citation: Sato, T.; Orimo, S.-i. The Crystal Structures in Hydrogen

Absorption Reactions of

$\mathrm{REMgNi}_{4}$-Based Alloys (RE:

Rare-Earth Metals). Energies 2021, 14, 8163. https://doi.org/10.3390/ en14238163

Academic Editors: George Avgouropoulos and Smagul Karazhanov

Received: 18 October 2021

Accepted: 1 December 2021

Published: 6 December 2021

Publisher's Note: MDPI stays neutral with regard to jurisdictional claims in published maps and institutional affiliations.

Copyright: (c) 2021 by the authors. Licensee MDPI, Basel, Switzerland. This article is an open access article distributed under the terms and conditions of the Creative Commons Attribution (CC BY) license (https:/ / creativecommons.org/licenses/by/ $4.0 /)$.

\begin{abstract}
REMgNi}_{4}$-based alloys, $\mathrm{RE}_{(2-\mathrm{x})} \mathrm{Mg}_{\mathrm{x}} \mathrm{Ni}_{4}$ (RE: rare-earth metals; $0<\mathrm{x}<2$ ), with a AuBe ${ }_{5}$ type crystal structure, exhibit reversible hydrogen absorption and desorption reactions, which are known as hydrogen storage properties. These reactions involve formation of three hydride phases. The hydride formation pressures and hydrogen storage capacities are related to the radii of the $\mathrm{RE}_{(2-\mathrm{x})} \mathrm{Mg}_{\mathrm{x}} \mathrm{Ni}_{4}$, which in turn are dependent on the radii and compositional ratios of the RE and $\mathrm{Mg}$ atoms. The crystal structures formed during hydrogen absorption reactions are the key to understanding the hydrogen storage properties of $\mathrm{RE}_{(2-x)} \mathrm{Mg}_{x} \mathrm{Ni}_{4}$. Therefore, in this review, we provide an overview of the crystal structures in the hydrogen absorption reactions focusing on $\mathrm{RE}_{(2-\mathrm{x})} \mathrm{Mg}_{\mathrm{x}} \mathrm{Ni}_{4}$.
\end{abstract}

Keywords: hydrogen storage materials; hydrides; crystal structures

\section{Introduction}

Hydrogen is a unique element, since it exhibits various hydrogen states in compounds (hydrides), which are elemental hydrogen, protons, hydride ion, and covalently bonded hydrogen [1]. Such hydrogen states lead to attractive physical and material properties. For these reasons, hydrides have been focused on in relation to energy-related materials [2-9]. In particular, hydrides (so-called material-based storage, or metal hydrides) have higher volumetric hydrogen densities than compressed $\mathrm{H}_{2}$ gas and liquid $\mathrm{H}_{2}$ [2-5,7].

To date, $\mathrm{LaNi}_{5}$-based alloys ( $\mathrm{AB}_{5}$ alloys) have been used in practical applications because of their stable reversible hydrogen absorption and desorption reactions under moderate conditions (i.e., room temperature and hydrogen gas pressure less than $1 \mathrm{MPa}$ ). By contrast, new hydrogen storage materials have higher gravimetric hydrogen densities than the $\mathrm{AB}_{5}$ alloys (approximately 1.4 mass \%) explored. In particular, $\mathrm{Mg}$ is a potential candidate because it is inexpensive, abundant in nature, and reacts with hydrogen to form $\mathrm{MgH}_{2}$ with high gravimetric hydrogen density (7.6 mass\%) [7]. However, in order to use $\mathrm{Mg}$ as a practical hydrogen storage material, it is necessary to improve the thermodynamic stability of $\mathrm{MgH}_{2}$, which is $-74 \mathrm{~kJ} / \mathrm{mol}$, corresponding to hydrogen release at approximately $550 \mathrm{~K}$ under ambient pressure. Alloying with transition metals has been attempted to improve the thermodynamic stability. Although $\mathrm{Mg}_{2} \mathrm{NiH}_{4}$ and $\mathrm{Mg}_{2} \mathrm{FeH}_{6}$ have been proposed, they are still too stable $\left(\mathrm{Mg}_{2} \mathrm{NiH}_{4}:-62 \mathrm{~kJ} / \mathrm{mol} \mathrm{H}{ }_{2} ; \mathrm{Mg}_{2} \mathrm{FeH}_{6}:-77 \mathrm{~kJ} / \mathrm{mol} \mathrm{H}\right)$ to release hydrogen at ambient temperatures [7]. The value should be approximately $-30 \mathrm{~kJ} / \mathrm{mol} \mathrm{H}$ for reversible hydrogen absorption and desorption reactions at ambient temperatures. In such hydrides, hydrogen atoms are ionically bonded with $\mathrm{Mg}$ in $\mathrm{MgH}_{2}$ or covalently bonded with $\mathrm{Ni}$ or Fe atoms in $\mathrm{Mg}_{2} \mathrm{NiH}_{4}$ [10] and $\mathrm{Mg}_{2} \mathrm{FeH}_{6}$ [11], respectively. Thus, these are ionic and complex hydrides. Qualitatively, such chemical bonding between the metal and hydrogen atoms induces hydrogen absorption and desorption reactions with high thermodynamic stability or slow kinetics. 
Therefore, understanding of hydrogen states in hydrides [1,12,13] is a key for development hydrogen storage materials which can operate moderate conditions. In fact, the design of intermetallic compounds that do not form ionic or complex hydrides is one approach to obtain efficient hydrogen storage materials. So far, $R E M g N i_{4}$-based alloys, such as $\mathrm{RE}_{(2-\mathrm{x})} \mathrm{Mg}_{\mathrm{x}} \mathrm{Ni}_{4}$ (RE: rare-earth metals; $0<x<2$ ), have been reported to exhibit reversible hydrogen absorption and desorption reactions at ambient temperatures [14-33]. In these reactions, hydrogen atoms are located at interstitial sites in the lattice of $\mathrm{RE}_{(2-\mathrm{x})} \mathrm{Mg}_{\mathrm{x}} \mathrm{Ni}_{4}$ and three hydride phases are formed [19-24,28-33]: $\mathrm{REMgNi}_{4} \mathrm{H}_{\mathrm{x} 1}, \mathrm{REMgNi}_{4} \mathrm{H}_{\mathrm{x} 2}$, and $\mathrm{REMgNi}_{4} \mathrm{H}_{\mathrm{x} 3}$. In this paper, we refer to $\mathrm{REMgNi}_{4} \mathrm{H}_{\mathrm{x} 1}, \mathrm{REMgNi}_{4} \mathrm{H}_{\mathrm{x} 2}$, and $\mathrm{REMgNi}_{4} \mathrm{H}_{\mathrm{x} 3}$ as the $\alpha-, \beta$-, and $\gamma$-hydride phases, respectively. The experimentally reported hydride phases with their unit cell parameters, formation enthalpy of the hydrides, and hydrogen contents are listed in Table 1.

Table 1. The experimentally reported hydride phases of $\mathrm{REMgNi}_{4}$-based alloys with unit cell parameters, formation enthalpy of the hydride $\Delta \mathrm{H}$, and hydrogen contents (an asterisk indicates enthalpy of the hydride, which was obtained from the hydrogen release reaction).

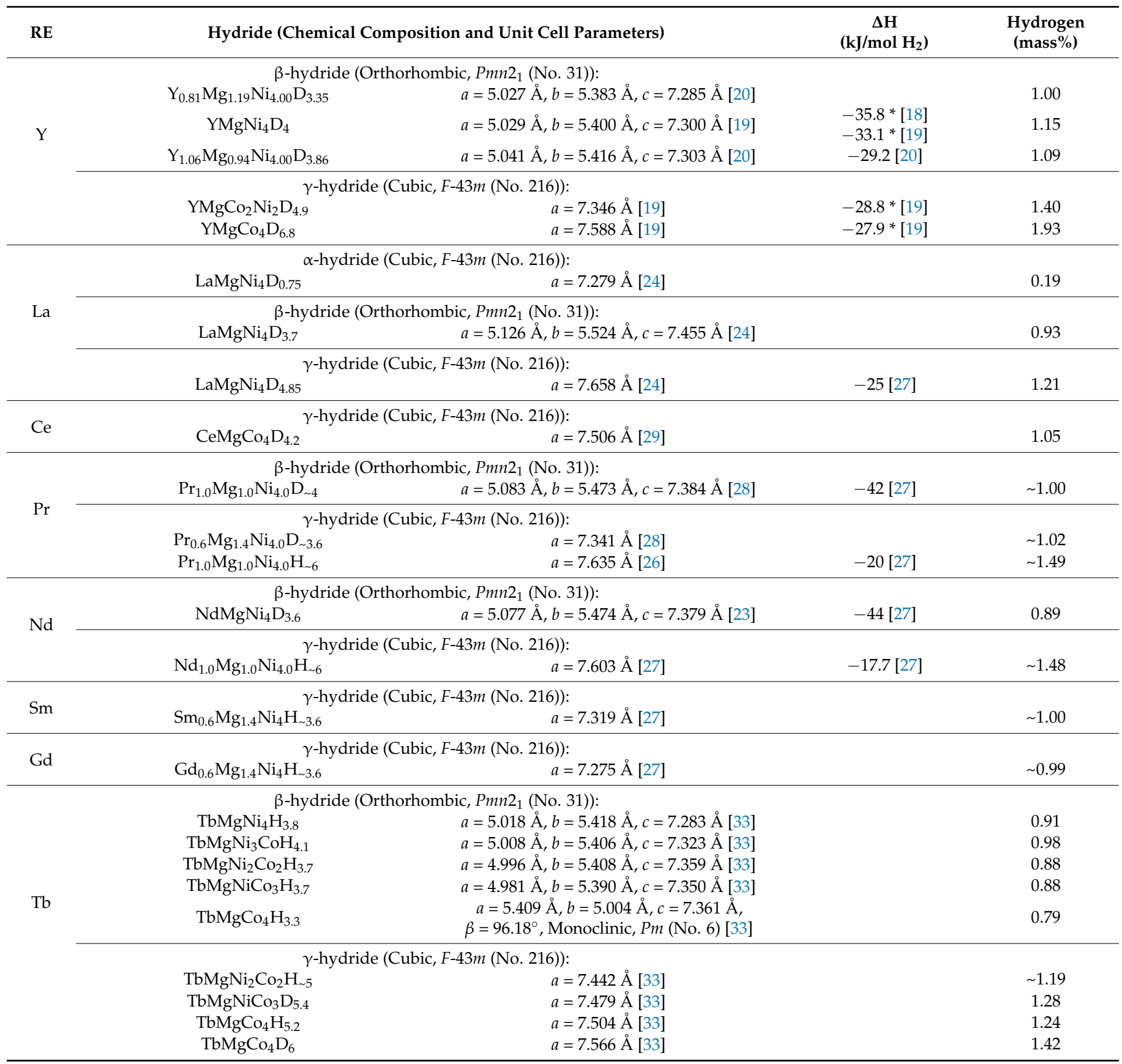


In $\mathrm{RE}_{(2-\mathrm{x})} \mathrm{Mg}_{\mathrm{x}} \mathrm{Ni}_{4}$, the atomic radii of the components, which are influenced by the addition of $\mathrm{Mg}$ with a smaller atomic radius than RE atoms [34], selection (radius) of the RE element, and compositional ratios, are crucial parameters for reversible hydrogen absorption and desorption reactions [14-16,18-33] and for avoiding hydrogen-induced amorphization (HIA) [35,36]. Absorbed hydrogen in $\mathrm{RENi}_{2}$ without $\mathrm{Mg}$ is hardly released at ambient temperature because of the considerably lower hydrogen desorption pressure than the ambient pressure. By contrast, $\mathrm{Mg}$ in $\mathrm{RENi}_{2}$, which forms $\mathrm{RE}_{(2-\mathrm{x})} \mathrm{Mg}_{\mathrm{x}} \mathrm{Ni}_{4}$, leads to increased equilibrium hydrogen absorption and desorption reaction pressures [20]. The atomic radii of components can also be adjusted by the selection (radius) of RE elements and compositional ratios because the unit cell parameters also depend on the RE element [17]. This indicates that the hydrogen absorption and desorption reactions are related to the interatomic spaces between metal atoms in the crystal structure. Furthermore, the radii of the components are related to the HIA because the HIA originates in the radius ratio between $\mathrm{RE}$ and $\mathrm{Ni}$ in the case of $\mathrm{RENi}_{2}$. In $\mathrm{REMgNi}_{4}, \mathrm{Mg}$ atoms share positions with two crystallographically different atomic sites of the RE element, and the atomic radius is averaged for $\mathrm{Mg}$ and $\mathrm{RE}$ atoms. Because the $\mathrm{Mg}$ atom is smaller than the RE atoms, the radius ratio of the components of $\mathrm{RE}_{(2-\mathrm{x})} \mathrm{Mg}_{\mathrm{x}} \mathrm{Ni}_{4}$ is smaller than that of pure $\mathrm{RENi}_{2}$ and leads to prevention of HIA.

For these reasons, $\mathrm{RE}_{(2-\mathrm{x})} \mathrm{Mg}_{\mathrm{x}} \mathrm{Ni}_{4}$, with various $\mathrm{RE}$ elements, has been investigated. In the Refs. [18-22], the hydrogen storage properties and crystal structures focusing on $\mathrm{RE}=\mathrm{Y}$ have been described. In the $\mathrm{RE}_{(2-\mathrm{x})} \mathrm{Mg}_{\mathrm{x}} \mathrm{Ni}_{4}$ alloys, $\mathrm{RE}=\mathrm{Y}$ is expected to have a higher gravimetric hydrogen density because $\mathrm{Y}$ is the lightest RE element that forms $\mathrm{REMgNi}_{4}$. However, the formation of the $\gamma$-hydride phase has not yet been reported [18-22]. Computational studies of $\mathrm{YMgNi}_{4}$ have been reported to investigate crystal structure and the thermodynamic stabilities [21,22]. Shtender et al. reported that the $\gamma$-hydride phase was formed by Co doping in $\mathrm{Ni}$ atomic sites as in $\mathrm{YMgNi}_{2} \mathrm{Co}_{2}$ or $\mathrm{YMgCo}_{4}$ [19]. Although most studies on $\mathrm{RE}_{(2-\mathrm{x})} \mathrm{Mg}_{\mathrm{x}} \mathrm{Ni}_{4}$ have mainly focused on $\mathrm{Ni}$ [14-28], Co doping at Ni atomic sites or replacement of $\mathrm{Ni}$ atoms with $\mathrm{Co}$ have also been attempted in $\mathrm{RE}=\mathrm{La}$ [25], Ce [29], $\operatorname{Pr}[30], \mathrm{Nd}[30,31]$, and $\mathrm{Tb}$ [32,33], in which, Co could lead to increased hydrogen storage capacities and decreased equilibrium hydrogen absorption reactions. A new hydride phase with a monoclinic structure has been reported [33]. The hydrogen storage properties of lanthanoids [27] and crystal structures, including local atomic arrangements focusing on $\mathrm{RE}=\operatorname{Pr}[26,28]$, were studied by Sakaki et al. Systematic studies have indicated that the radii of RE atoms have a greater influence than lanthanide type on hydrogen storage properties.

Thus, hydrogen absorption and desorption reaction pressures and maintaining the crystallinities of hydrogen storage alloys can be controlled by the appropriate selection (radius) of the RE element and the compositional ratio between the RE and $\mathrm{Mg}$. This is a design strategy for $\mathrm{REMgNi}_{4}$-based alloys, although the properties of other hydrogen storage alloys have been demonstrated to be controlled by the replacement of various elements. To further understand the hydrogen storage properties, with respect to the atomic arrangements, detailed analysis of crystal structures during the hydrogen absorption reactions is critical. This is because the information on metal atomic arrangements around hydrogen atoms in the crystal structures could be related to the hydrogen storage properties. The metal atomic arrangements of the $\alpha-, \beta-$, and $\gamma$-hydride phases, which adopt different crystal structures, are maintained. However, some hydride phases have been reported to become complicated, resulting in distorted metal atomic arrangements and different hydrogen atomic positions. Herein, we provide an overview of the crystal structural changes during the hydrogen absorption reactions focusing on $\mathrm{REMgNi}_{4}$.

\section{Crystal Structures}

\section{1. $\mathrm{REMgNi}_{4}$}

$\mathrm{REMgNi}_{4}$ adopts a face-centered cubic (FCC) structure (AuBe 5 type) in the space group F-43m (No. 216) with $Z=4$, which resembles a Laves phase alloy with a C15-type $\left(\mathrm{MgCu}_{2}\right.$ type) crystal structure in the space group $F d-3 m$ (No. 227) with $Z=8$. The crystal 
structures of $\mathrm{REMgNi}_{4}$ and a Laves phase alloy, $\mathrm{RENi}_{2}$, with a C15-type crystal structure, are illustrated in Figure 1.

(a) $\mathrm{REMgNi}_{4}(F-43 m$ (No. 216))

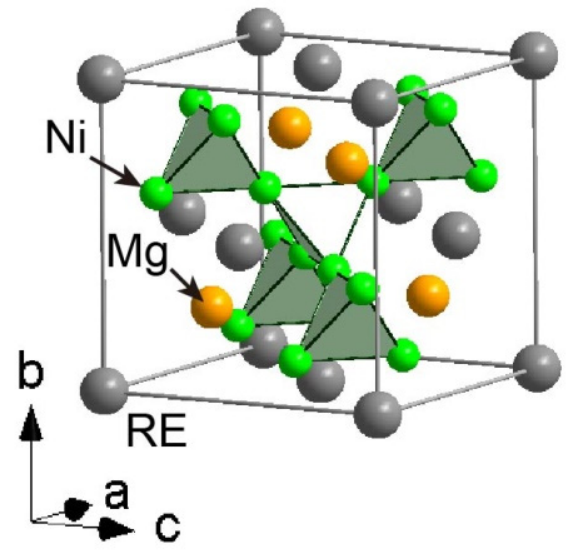

(b) $\operatorname{RENi}_{2}(F d-3 m($ No. 227))

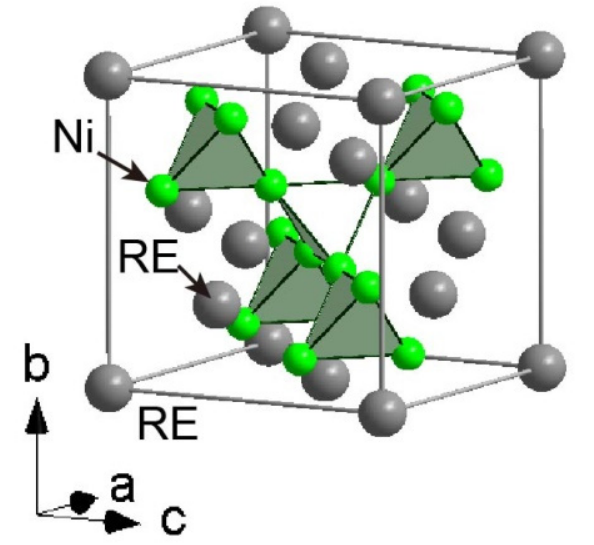

Figure 1. Crystal structures of (a) $\mathrm{REMgNi}_{4}$ in the space group ( $F-43 m$ (No. 216) and (b) $\mathrm{RENi}_{2}$ in the space group $F d-3 m$ (No. 227, origin choice 1). Crystal structures of $\mathrm{REMgNi}_{4}$ and $\mathrm{RENi}_{2}$ were drawn based on crystallographic parameters of $\mathrm{Y}_{1.06} \mathrm{Mg}_{0.94} \mathrm{Ni}_{4.00}$ [20] and $\mathrm{YNi}_{2}$ [37], respectively. The RE, $\mathrm{Mg}$, and $\mathrm{Ni}$ atoms are represented by grey, orange, and green spheres, respectively.

The differences between the two crystal structures are apparent at the $(0,0,0)$ and $(1 / 4,1 / 4,1 / 4)$ atomic sites. In the $\mathrm{REMgNi}_{4}$, the $\mathrm{RE}$ and $\mathrm{Mg}$ atoms are located at $(0$, $0,0)$ and $(1 / 4,1 / 4,1 / 4)$, respectively, such that the atoms are distinguishable. In the $\mathrm{RENi}_{2}, \mathrm{RE}$ atoms are located at both $(0,0,0)$ and $(1 / 4,1 / 4,1 / 4)$, with the latter position generated by the RE atoms at $(0,0,0)$ due to the symmetry operation of the space group Fd-3m (No. 227, origin choice 1$)$. Therefore, the atoms at $(0,0,0)$ and $(1 / 4,1 / 4,1 / 4)$ are indistinguishable. To understand the differences in $\mathrm{X}$-ray diffraction patterns, a Laves phase alloy, $\mathrm{CaNi}_{2}$, is considered in this paper although $\mathrm{Ca}$ is not a rare earth metal element. $\mathrm{CaNi}_{2}$ has a Laves phase alloy, and $\mathrm{Ca}_{1-x} \mathrm{Mg}_{x} \mathrm{Ni}_{2}$ has been reported [14,17]. In $\mathrm{Ca}_{1-x} \mathrm{Mg}_{x} \mathrm{Ni}_{2}$, some of the $\mathrm{Ca}$ atoms in the $\mathrm{CaNi}_{2}$ Laves phase alloy are replaced by $\mathrm{Mg}$ atoms in a disordered arrangement. This indicates that $\mathrm{Ca}_{1-x} \mathrm{Mg}_{\mathrm{x}} \mathrm{Ni}_{2}$ has a $\mathrm{C} 15$-type $\left(\mathrm{MgCu}_{2}\right.$ type) crystal structure in the space group $F d-3 m$ (No. 227) with $Z=8$. If $\mathrm{Ca}$ and $\mathrm{Mg}$ atoms are ordered arrangements with $x=0.5$, the crystal structure of $\mathrm{Ca}_{0.5} \mathrm{Mg}_{0.5} \mathrm{Ni}_{2}\left(=\mathrm{CaMgNi}_{4}\right)$ is described in the space group $F-43 m$ (No. 216) as well as REMgNi ${ }_{4}$. Simulated X-ray diffraction patterns of $\mathrm{Ca}_{0.5} \mathrm{Mg}_{0.5} \mathrm{Ni}_{2}$ in the space group $F d-3 m$ (No. 227) and hypothetical $\mathrm{CaMgNi}_{4}$ in the space group F-43m (No. 216) are shown in Figure 2.

The differences between the two diffraction patterns are apparent in the $(00 l)$ reflections, which appear at $d=3.49 \AA$ (002) and $d=1.16 \AA$ (006). In the case of $F d-3 m$ (No. 227), the (002) and (006) reflections are forbidden because of the systematic absences $(l: 4 \mathrm{n})$ in the space group, although their reflections appear in the space group F-43m (No. 216). Therefore, the $(00 l)$ reflections indicate the crystal structure-types. In $\mathrm{REMgNi}_{4}$-based alloys in the space group F-43m (No. 216), some of the RE atoms are replaced by $\mathrm{Mg}$ atoms and vice versa $\left(\mathrm{RE}_{(2-\mathrm{x})} \mathrm{Mg}_{\mathrm{x}} \mathrm{Ni}_{4}, 0<\mathrm{x}<2\right)$. Although the arrangement of the $\mathrm{RE}$ and $\mathrm{Mg}$ atoms is disordered, their site occupations at $(0,0,0)$ and $(1 / 4,1 / 4,1 / 4)$ differ. In $\mathrm{RE}_{(2-\mathrm{x})} \mathrm{Mg}_{\mathrm{x}} \mathrm{Ni}_{4}$, hydrogen absorption and desorption pressures (so-called plateau pressures) increase with increasing amounts of $\mathrm{Mg}$, owing to a decreasing unit cell size that restricts the space available to hydrogen atomic sites. Affinities between metal and hydrogen atoms would relate with the reactions. 


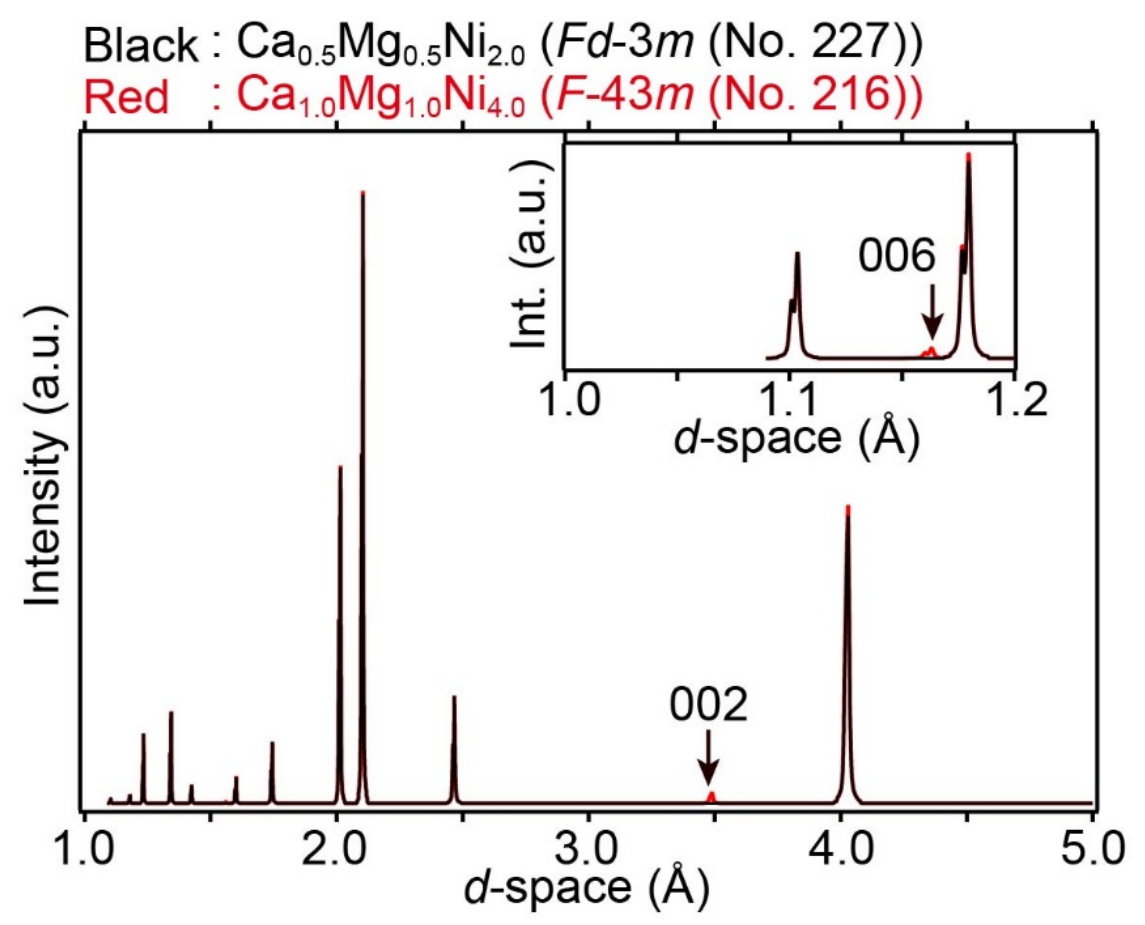

Figure 2. Simulated X-ray diffraction patterns of (black) $\mathrm{Ca}_{0.5} \mathrm{Mg}_{0.5} \mathrm{Ni}_{2.0}$ in the space group $F d-3 m$ (No. 227) and (red) hypothetical $\mathrm{Ca}_{1.0} \mathrm{Mg}_{1.0} \mathrm{Ni}_{4.0}$ in the space group F-43m (No. 216). For the simulation, $\mathrm{Cu} \mathrm{K} \alpha$ radiation (wavelength $\lambda=1.5406$ and $1.5444 \AA$ for $\mathrm{K} \alpha 1$ and $\mathrm{K} \alpha 2$, respectively) was used. For the simulation, unit cell parameters of $(\mathrm{Ca}, \mathrm{Mg}) \mathrm{Ni}_{2}$ were used [14]. Inset shows an enlarged pattern at $1.0 \leq d \leq 1.2 \AA$ of the X-ray diffraction of $\mathrm{Ca}_{0.5} \mathrm{Mg}_{0.5} \mathrm{Ni}_{2.0}$ and $\mathrm{Ca}_{1.0} \mathrm{Mg}_{1.0} \mathrm{Ni}_{4.0}$. (002) and (006) reflection, which are the systematic absence of the space group Fd-3m (No. 227), are indicated by arrows.

\section{2. $\alpha$-Hydride Phase $\left(R E M g N i_{4} H_{x 1}\right)$}

The crystal structure of the $\alpha$-hydride phase has been reported in the hydrogen absorption reactions of $\mathrm{LaMgNi}_{4}$ (Figure 3). This hydride phase is formed at $0.5 \mathrm{MPa}$ at $373 \mathrm{~K}$ [24]. The unit cell is slightly expanded compared with that of the alloy phase, and hydrogen atoms were located in a tetrahedral site coordinated by four $\mathrm{Ni}$ atoms. We recently reported that the alloy phases of $\mathrm{Y}_{(2-\mathrm{x})} \mathrm{Mg}_{\mathrm{x}} \mathrm{Ni}_{4}(0<\mathrm{x}<2)$ with larger unit cell parameters $(Y>>M g)$ form the $\alpha$-hydride phase, which correspond to lower reversible hydrogen storage capacities because the $\alpha$-hydride phase is thermodynamically stable and does not release hydrogen at $323 \mathrm{~K}$. In the case where there are more $\mathrm{Y}$ atoms than $\mathrm{Mg}$ atoms $\left(\mathrm{Y}>>\mathrm{Mg}\right.$ in $\left.\mathrm{Y}_{(2-\mathrm{x})} \mathrm{Mg}_{\mathrm{x}} \mathrm{Ni}_{4}(0<\mathrm{x}<2)\right)$, after hydrogen absorption, poor crystallinity (hydrogen-induced amorphization (HIA) [35,36]) has also been observed [20]. HIA is related to the atomic radii of the components. Thus, in general, less $\mathrm{Mg}$ decreases the reversible hydrogen storage capacity through $\alpha$-hydride phase formation and results in $\mathrm{HIA}$, although the precise values of Mg depend on the RE elements. 


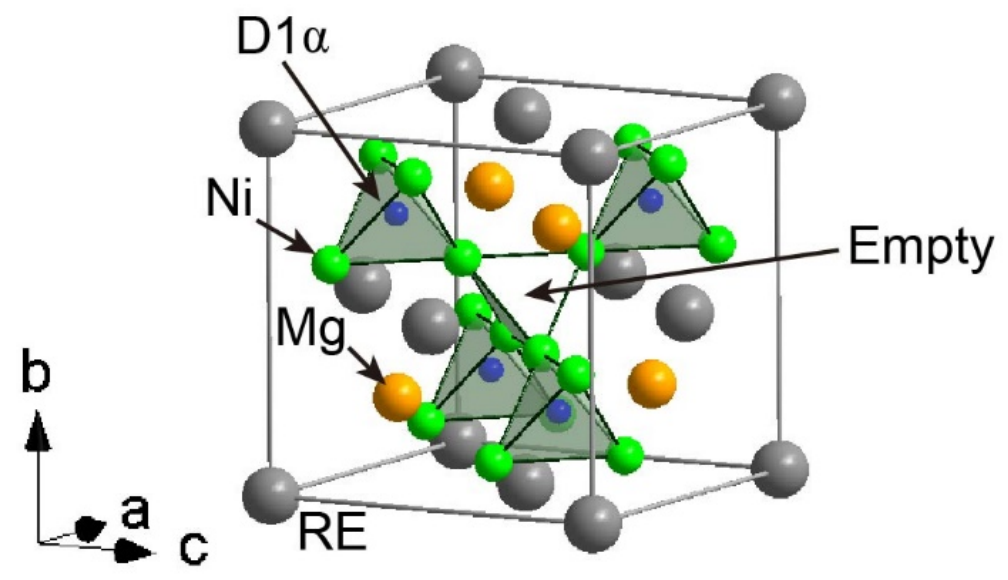

Figure 3. Crystal structure of $\alpha$ hydride based on $\mathrm{LaMgNi}_{4} \mathrm{D}_{0.75}$ [24]. The $\mathrm{RE}, \mathrm{Mg}$, and $\mathrm{Ni} \mathrm{D}$ atoms are represented by grey, orange, and green spheres, respectively. The corner-shared tetrahedra formed by four Ni atoms are represented as the green polyhedra. The D atoms in the crystal structure are indicated as $\mathrm{D} 1 \alpha$.

\section{3. $\beta$-Hydride Phase $\left(\mathrm{REMgNi}_{4} \mathrm{H}_{x 2}\right)$}

The $\beta$-hydride phase is formed at a hydrogen pressure less than $10 \mathrm{MPa}$ below $373 \mathrm{~K}$. Therefore, the $\beta$-hydride phase is mainly obtained as the hydride phase of $\mathrm{RE}_{(2-x)} \mathrm{Mg}_{x} \mathrm{Ni}_{4}$ under a moderate hydrogen pressure range.

The $\beta$-hydride phase adopts an orthorhombic unit cell in the space group $P m n 2_{1}$ (No. 31) with $Z=2$. Although the crystal system is different from the alloy phase, the same metal atomic arrangements of $\mathrm{REMgNi}_{4}$ (but distorted) were found in the crystal structure (Figure 4).
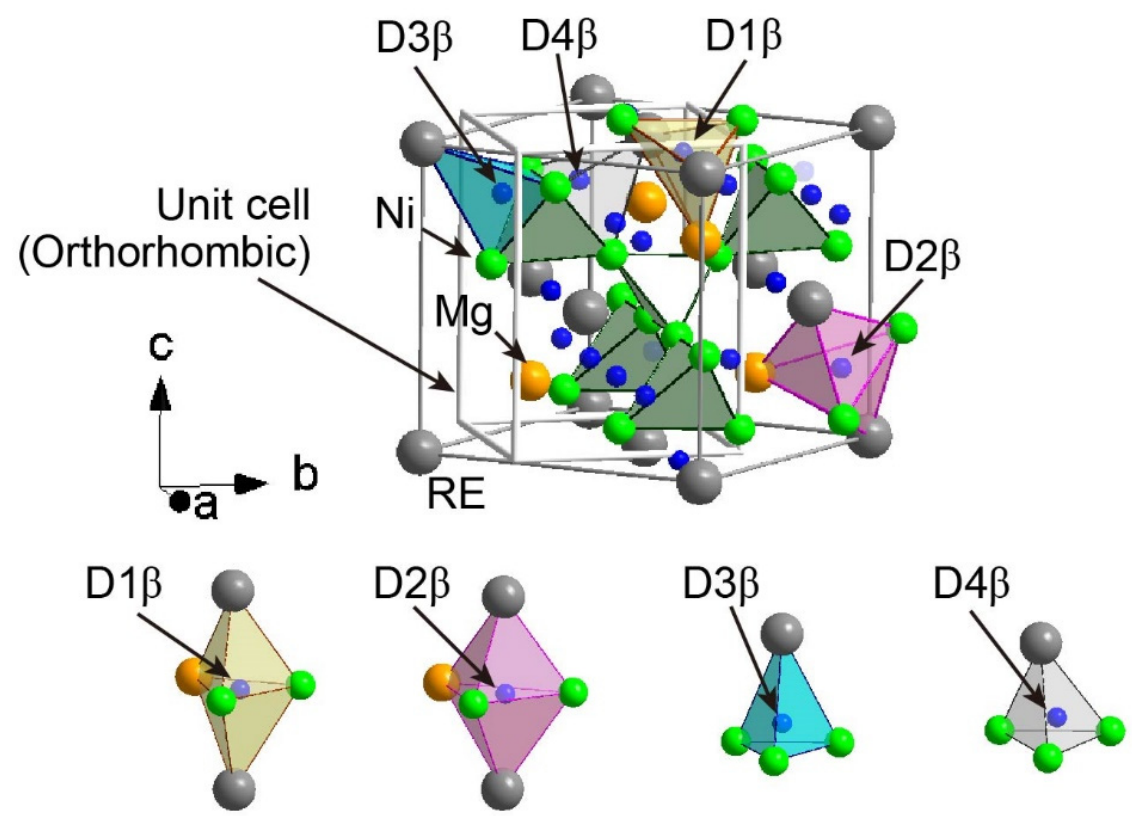

Figure 4. Crystal structure of $\beta$ hydride, based on $\mathrm{Y}_{1.06} \mathrm{Mg}_{0.94} \mathrm{Ni}_{4.00} \mathrm{D}_{3.86}$ [20]. The $\mathrm{Y}, \mathrm{Mg}$, and Ni D atoms are represented by grey, orange, and green circles, respectively. Parts of $\mathrm{Mg}$ atoms are replaced by $\mathrm{Y}$ atoms. The corner-shared tetrahedra formed by four $\mathrm{Ni}$ atoms are represented as the green polyhedra. The original orthorhombic unit cell is represented as white line. The grey lines connect the $\mathrm{Y}$ atoms in $\mathrm{Y}_{1.06} \mathrm{Mg}_{0.94} \mathrm{Ni}_{4.00} \mathrm{D}_{3.86}$ to compare it with the unit cell of $\mathrm{REMgNi}_{4}$ (Figure 1). In the local atomic arrangements around the $\mathrm{D}$ atoms, the hydrogen sites in the triangular bipyramid, and the tetrahedra are represented as yellow (D1 $\beta)$, pink (D2 $\beta)$, cyan (D3 $\beta)$, and green (D4 $\beta)$ polyhedral, respectively. 
Hydrogen atoms are located inside the triangular bipyramids and tetrahedra. The triangular bipyramid is formed by two $\mathrm{RE}$, one $\mathrm{Mg}$, and two $\mathrm{Ni}$ atoms, and the tetrahedron is formed by one RE and three Ni atoms. When there are more RE atoms than $\mathrm{Mg}$ atoms, the volumes of the hydrogen atomic sites are expanded, and the hydrogen storage capacities are increased [20]. As mentioned above, increasing the volume of the unit cell induces the formation of thermodynamically stable $\alpha$-hydride phases, which are responsible for the lower reversible hydrogen storage capacities reported for $\mathrm{Y}_{(2-\mathrm{x})} \mathrm{Mg}_{\mathrm{x}} \mathrm{Ni}_{4}(0<\mathrm{x}<2)$ [20]. In $\mathrm{Y}_{(2-\mathrm{x})} \mathrm{Mg}_{\mathrm{x}} \mathrm{Ni}_{4}(0<\mathrm{x}<2)$, the alloys with slightly more $\mathrm{Y}$ atoms than $\mathrm{Mg}$ atoms exhibited the highest reversible hydrogen storage capacities [20]. The affinity of metal atoms around hydrogen atoms is speculated to be related to hydrogen storage properties, in addition to the space available to the hydrogen atomic sites.

To date, the $\beta$-hydride has been reported to have three crystallographically different hydrogen atomic sites $(\mathrm{D} 1 \beta, \mathrm{D} 2 \beta$, and $\mathrm{D} 3 \beta)$, and $\mathrm{Y}_{(2-\mathrm{x})} \mathrm{Mg}_{\mathrm{x}} \mathrm{Ni}_{4}(0<\mathrm{x}<2)$ has one extra hydrogen atomic site (D4 $\beta$ in Figure 4$)$. The amount of extra D $4 \beta$ hydrogen atomic sites increased with increasing amounts of $Y$ atoms, and the positions were the same as those of the hydrogen atoms in the $\gamma$-hydride phase. Although the $\gamma$-hydride phase of $\mathrm{Y}_{(2-\mathrm{x})} \mathrm{Mg}_{\mathrm{x}} \mathrm{Ni}_{4}(0<\mathrm{x}<2)$ could not be observed [20], an increase in the occupancies of D4 $\beta$ might lead to the formation of the $\gamma$-hydride phase (the hydrogen atomic positions in the $\gamma$-hydride phase are shown in the next section). Notably, the extra hydrogen atomic sites have $\mathrm{H}-\mathrm{H}$ interatomic distances shorter than $2.1 \AA$, which correspond to the shortest $\mathrm{H}-\mathrm{H}$ interatomic distances in hydrides [38]. Although hydrogen atomic pairs with short interatomic distances might not simultaneously exist at each atomic site, such short $\mathrm{H}-$ $\mathrm{H}$ interatomic distances have been reported in the $\gamma$ hydride [28] as well as the other hydrides [39-41].

Related to the $\beta$-hydride phase with the orthorhombic unit cell, a $\mathrm{TbMgCo}_{4}$ hydride phase with a monoclinic unit cell in the space group Pm (No. 6) has been reported [33]. The details of hydrogen atomic positions in the monoclinic structure are not presented in the Ref. [33].

\subsection{Y-Hydride Phase ( $\left.\mathrm{REMgNi}_{4} \mathrm{H}_{x 3}\right)$}

The $\gamma$-hydride phase formed at higher hydrogen pressures and had higher storage capacities than the $\alpha$ and $\beta$ hydrides. As mentioned above, the hydrogen pressure depends on the types of RE and the compositional ratios between the RE and $\mathrm{Mg}$ atoms. This is because the equilibrium hydrogen pressure for the $\gamma$-hydride phase decreases if the $\beta$ hydride is formed at a lower pressure. A larger unit cell size and lower amounts of $\mathrm{Mg}$ induce the absorption of hydrogen at lower hydrogen pressures and form a thermodynamically stable $\alpha$-hydride phase with lower reversible hydrogen storage capacities. Thus, it is important to form the $\gamma$-hydride phase at a lower equilibrium hydrogen pressure without the formation of the $\alpha$-hydride phase to maintain higher hydrogen storage capacities. In addition to optimizing the compositional ratios between $\mathrm{RE}$ and $\mathrm{Mg}$, another approach is the replacement of a portion of the $\mathrm{Ni}$ atoms with transition metals (e.g., Co) [19,29-33]. With the replacement of $\mathrm{Ni}$ with $\mathrm{Co}$, the hydrogen storage capacity of $\mathrm{YMgCo}_{4}$ was found to be higher than that of $\mathrm{LaNi}_{5}$ [19].

The $\gamma$-hydride phase has an FCC crystal structure in the space group F-43m (No. 216) with $Z=4$ (Figure 5). Two crystal structure models have been reported. One is $\mathrm{LaMgNi}_{4} \mathrm{H}_{4.85}$, wherein hydrogen atoms are located inside the triangular bipyramid coordinated by two $\mathrm{La}$, one $\mathrm{Mg}$, and two $\mathrm{Ni}$ atoms and a tetrahedron coordinated by four Ni atoms. The hydrogen atoms in the tetrahedron $(1 / 2,1 / 2,1 / 2)$ have different atomic positions from hydrogen atoms $(3 / 4,3 / 4,3 / 4)$ in the $\alpha$-hydride phase. The other is $\operatorname{Pr}_{0.6} \mathrm{Mg}_{1.4} \mathrm{Ni}_{4} \mathrm{H}_{3.6}$, wherein a portion of the $\mathrm{Mg}$ atoms are located at the Pr atomic positions. The hydrogen atoms inside the triangular bipyramid are coordinated by two $\operatorname{Pr}(\mathrm{Mg})$, one $\mathrm{Mg}$, and two $\mathrm{Ni}$ atoms and a tetrahedron coordinated by one $\operatorname{Pr}(\mathrm{Mg})$ and three Ni atoms. The difference between LaMgNi $\mathrm{H}_{4.85}$ and $\mathrm{Pr}_{0.6} \mathrm{Mg}_{1.4} \mathrm{Ni}_{4} \mathrm{H}_{3.6}$ is the hydrogen atomic sites in the tetrahedral sites (see Figure 5). The hydrogen atomic sites in $\operatorname{Pr}_{0.6} \mathrm{Mg}_{1.4} \mathrm{Ni}_{4} \mathrm{H}_{3.6}$ are similar to those of the $\beta$ 
hydride (see Figures 4 and $5 b$ ). In particular, the D2 $\gamma$ hydrogen atomic site has the same local atomic arrangements as $\mathrm{D} 4 \beta$ in the $\beta$ hydride, $\mathrm{Y}_{1.06} \mathrm{Mg}_{0.94} \mathrm{Ni}_{4} \mathrm{D}_{3.86}$ (Figure 4). D4 $\beta$ atoms, which were observed in $\mathrm{Y}_{1.06} \mathrm{Mg}_{0.94} \mathrm{Ni}_{4.00} \mathrm{D}_{3.86}$ as extra hydrogen atomic sites with short D-D interatomic distances of less than $2.1 \AA$, are speculated to be a bridge between the $\beta$ - and $\gamma$-hydride phases.

(a) $\mathrm{LaMgNi}_{4} \mathrm{D}_{4.85}$
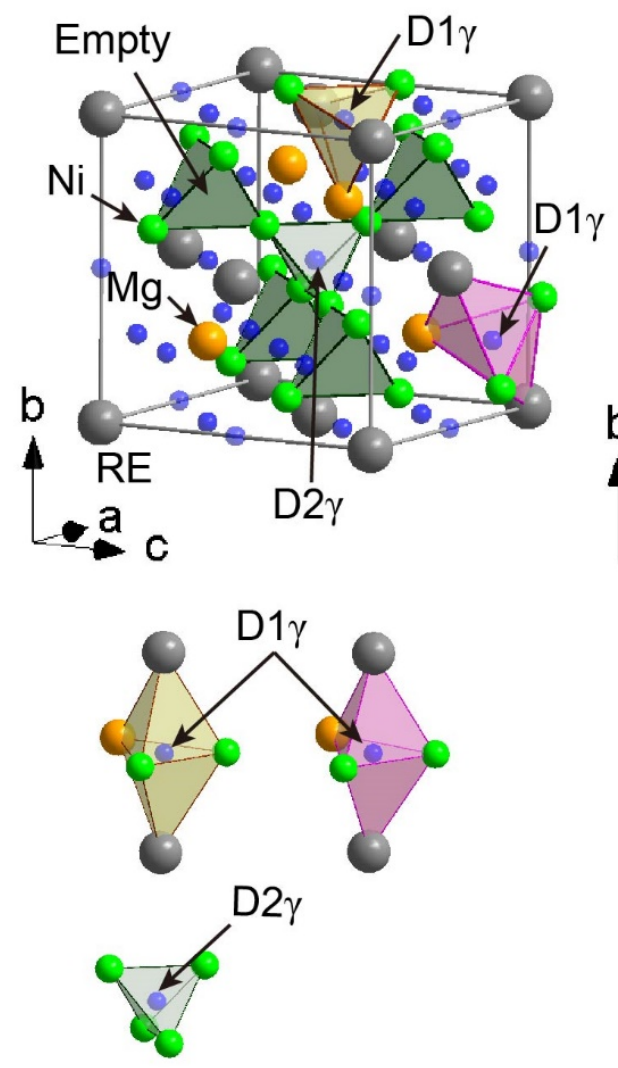

(b) $\mathrm{Pr}_{0.6} \mathrm{Mg}_{1.4} \mathrm{Ni}_{4} \mathrm{D}_{3.60}$
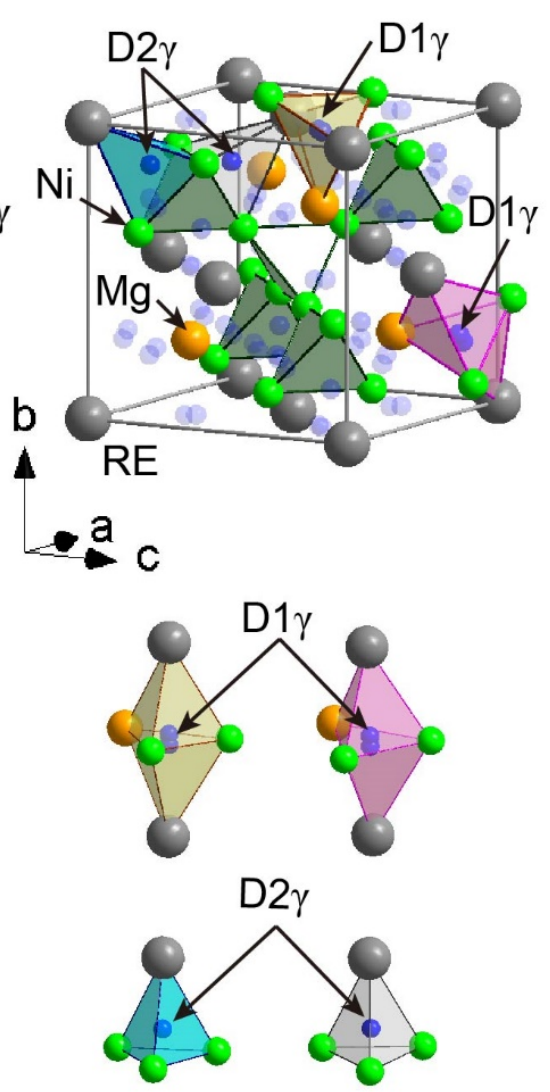

Figure 5. Crystal structures of $\gamma$ hydride phases based on (a) $\mathrm{LaMgNi}_{4} \mathrm{D}_{4.85}$ [24] and (b) $\mathrm{Pr}_{0.6} \mathrm{Mg}_{1.4} \mathrm{Ni}_{4} \mathrm{D}_{3.60}$. [28]. The $\mathrm{La}(\mathrm{Pr}), \mathrm{Mg}$, and $\mathrm{Ni} \mathrm{D}$ atoms are represented by grey, orange, and green spheres, respectively. Parts of $\mathrm{Pr}$ atoms are replaced by $\mathrm{Mg}$ atoms in $\operatorname{Pr}_{0.6} \mathrm{Mg}_{1.4} \mathrm{Ni}_{4} \mathrm{D}_{3.60}$. The corner-shared tetrahedra formed by four $\mathrm{Ni}$ atoms are represented as the green polyhedra. The original orthorhombic unit cell is represented as white line. In the local atomic arrangements around the D atoms, the hydrogen sites (D1 $\gamma)$ in the triangular bipyramid are represented as yellow and pink polyhedra. In the local atomic arrangements around the D atoms, the hydrogen sites (D2 $\gamma$ ) in the tetrahedra are represented as green $\left(\mathrm{LaMgNi}_{4} \mathrm{D}_{4.85}\right)$, cyan $\left(\operatorname{Pr}_{0.6} \mathrm{Mg}_{1.4} \mathrm{Ni}_{4} \mathrm{D}_{3.60}\right)$, and grey $\left(\mathrm{Pr}_{0.6} \mathrm{Mg}_{1.4} \mathrm{Ni}_{4} \mathrm{D}_{3.60}\right)$ polyhedra.

\section{Conclusions}

$\mathrm{REMgNi}_{4}$-based alloys, $\mathrm{RE}_{(2-\mathrm{x})} \mathrm{Mg}_{\mathrm{x}} \mathrm{Ni}_{4}$ (RE: rare-earth metals; $0<\mathrm{x}<2$ ), form three hydride phases-the $\alpha-, \beta-$, and $\gamma$-hydride phases-during the hydrogen absorption reactions.

In this paper, we provided overview of the crystal structures of the $\alpha-, \beta-$, and $\gamma-$ hydride phases. The $\alpha$-hydride phase has hydrogen atoms inside the tetrahedra, while the $\beta$ - and $\gamma$-hydride phases have similar hydrogen atoms inside the triangular bipyramid and tetrahedron. In particular, the $\beta$-hydride phase of $Y_{(2-x)} \mathrm{Mg}_{x} \mathrm{Ni}_{4}(0<x<2)$ has an extra hydrogen atomic site with a short $\mathrm{H}-\mathrm{H}$ interatomic distance of less than $2.1 \AA$, which has not been reported for other $\beta$-hydride phases. The atomic site has the same local atomic 
arrangement as the hydrogen atomic site in the $\gamma$-hydride phase and may be a bridge between the $\beta$ - and $\gamma$-hydride phases.

The higher hydrogen pressures required for the formation of the $\gamma$-hydride phase (with higher hydrogen storage capacity) could be decreased by increasing the unit cell sizes of the $\mathrm{RE}_{(2-\mathrm{x})} \mathrm{Mg}_{\mathrm{x}} \mathrm{Ni}_{4}$ with higher amounts of $\mathrm{RE}$ than $\mathrm{Mg}$. Although $\mathrm{RE}_{(2-\mathrm{x})} \mathrm{Mg}_{\mathrm{x}} \mathrm{Ni}_{4}$ with $\mathrm{RE}>>\mathrm{Mg}$ has larger unit cell sizes, it leads to the formation of a thermodynamically stable $\alpha$-hydride phase and a decrease in the reversible hydrogen storage capacity. Thus, the compositional ratios between $\mathrm{RE}$ and $\mathrm{Mg}$ should be optimized. In addition to the optimization of the compositional ratios, replacing Ni with Co can lead to the $\gamma$-hydride phase having a hydrogen storage capacity greater that of the hydrogen storage alloy, $\mathrm{LaNi}_{5}$, without the formation of a thermodynamically stable $\alpha$-hydride phase. For the reason, the REMgNi 4 based alloys, $\mathrm{RE}_{(2-\mathrm{x})} \mathrm{Mg}_{\mathrm{x}} \mathrm{Ni}_{4}$ (RE: rare-earth metals; $0<\mathrm{x}<2$ ), have potential as hydrogen storage materials that could replace $\mathrm{LaNi}_{5}$.

Author Contributions: T.S. conceived and wrote the manuscript. S.-i.O. supervised and discussed the manuscript. All authors have read and agreed to the published version of the manuscript.

Funding: This research was funded by JST SICORP, grant number JPMJSC 1802 and MEXT/JSPS KAKENHI "Hydrogenomics", grant number JP18H05513.

Institutional Review Board Statement: Not applicable.

Informed Consent Statement: Not applicable.

Data Availability Statement: The data presented in this study are available from the corresponding author upon request.

Conflicts of Interest: The authors declare no conflict of interest.

\section{References}

1. Takagi, S.; Orimo, S. Recent progress in hydrogen-rich materials from the perspective of bonding flexibility of hydrogen. Scr. Mater. 2015, 109, 1-5. [CrossRef]

2. Schlapbach, L.; Züttel, A. Hydrogen-storage materials for mobile applications. Nature 2001, 414, 353-358. [CrossRef] [PubMed]

3. Züttel, A. Materials for hydrogen storage. Mater. Today 2003, 6, 24-33. [CrossRef]

4. Orimo, S.; Nakamori, Y.; Eliseo, J.R.; Züttel, A.; Jensen, C.M. Complex hydrides for hydrogen storage. Chem. Rev. 2007, 107, 4111-4132. [CrossRef] [PubMed]

5. Eberle, U.; Felderhoff, M.; Schüth, F. Chemical and physical solutions for hydrogen storage. Angew. Chem. Int. Ed. 2009, 48, 6608-6630. [CrossRef]

6. Kim, S.; Oguchi, H.; Toyama, N.; Sato, T.; Takagi, S.; Otomo, T.; Arunkumar, D.; Kuwata, N.; Kawamura, J.; Orimo, S. A complex hydride lithium superionic conductor for high-energy-density all-solid-state lithium metal batteries. Nat. Commun. 2019, 10, 1081. [CrossRef]

7. Hirscher, M.; Yartys, V.A.; Baricco, M.; Bellosta von Colbe, J.; Blanchard, D.; Bowman, R.C.; Broom, D.P.; Buckley, C.E.; Chang, F.; Chen, P.; et al. Materials for hydrogen-based energy storage e past, recent progress and future outlook. J. Alloys Compd. 2020, 827, 153548. [CrossRef]

8. Takagi, S.; Ikeshoji, T.; Sato, T.; Orimo, S. Pseudorotating hydride complexes with high hydrogen coordination: A class of rotatable polyanions in solid matter. Appl. Phys. Lett. 2020, 116, 173901. [CrossRef]

9. Kisu, K.; Kim, S.; Shinohara, T.; Zhao, K.; Züttel, A.; Orimo, S. Monocarborane cluster as a stable fluorine-free calcium battery electrolyte. Sci. Rep. 2021, 11, 7563. [CrossRef]

10. Zolliker, P.; Yvon, K.; Jorgensen, J.D.; Rotella, F.J. Structural studies of the hydrogen storage material $\mathrm{Mg}_{2} \mathrm{NiH}_{4}$. 2. Monoclinic low-temperature structure. Inorg. Chem. 1986, 25, 3590-3593. [CrossRef]

11. Didisheim, J.-J.; Zolliker, P.; Yvon, K.; Fischer, P.; Schefer, J.; Gubelmann, M.; Williams, A.F. Dimagnesium iron (II) hydride, $\mathrm{Mg} 2 \mathrm{FeH}$, containing octahedral $\mathrm{FeH}_{6}{ }^{4-}$ anions. Inorg. Chem. 1984, 23, 1953-1957. [CrossRef]

12. Sato, T.; Ramirez-Cuesta, A.J.; Daemen, L.L.; Cheng, Y.; Orimo, S. Evidence of intermediate hydrogen states in the formation of a complex hydride. Inorg. Chem. 2018, 57, 867-872. [CrossRef]

13. Sato, T.; Daemen, L.L.; Cheng, Y.; Ramirez-Cuesta, A.J.; Ikeda, K.; Aoki, T.; Otomo, T.; Orimo, S. Hydrogen-release reaction of a complex transition metal hydride with covalently bound hydrogen and hydride ions. ChemPhysChem 2019, 20, 1392-1397. [CrossRef] [PubMed]

14. Terashita, N.; Akiba, E. Hydriding Properties of $\left(\mathrm{Mg}_{1-\mathrm{x}} \mathrm{M}_{\mathrm{x}}\right) \mathrm{Ni}_{2}$ C15-Type Laves Phase Alloys. Mater. Trans. 2006, 47, 1890-1893. [CrossRef] 
15. Zhanga, H.; Zhenga, X.; Tianb, X.; Liuc, Y.; Lia, X. New approaches for rare earth-magnesium based hydrogen storage alloys. Prog. Nat. Sci. Mater. Int. 2017, 27, 50-57. [CrossRef]

16. Modi, P.; Aguey-Zinsou, K.F. Room Temperature Metal Hydrides for Stationary and Heat Storage Applications: A Review. Front. Energy Res. 2021, 9, 616115. [CrossRef]

17. Kadir, K.; Noréus, D.; Yamashita, I. Structural Determination of $\mathrm{AMgNi}_{4}$ (Where $\mathrm{A}=\mathrm{Ca}, \mathrm{La}, \mathrm{Ce}, \mathrm{Pr}, \mathrm{Nd}$, and Y) in the AuBe 5 Type Structure. J. Alloys Compd. 2002, 345, 140-143. [CrossRef]

18. Aono, K.; Orimo, S.; Fujii, H. Structural and Hydriding Properties of $\mathrm{MgYNi}_{4}$ : A new intermetallic compound with C15b-type Laves phase structure. J. Alloys Compd. 2000, 309, L1-L4. [CrossRef]

19. Shtender, V.V.; Denys, R.V.; Paul-Boncour, V.; Riabov, A.B.; Zavaliy, I.Y. Hydrogenation Properties and Crystal Structure of YMgT 4 ( $\mathrm{T}=\mathrm{Co}, \mathrm{Ni}, \mathrm{Cu}$ ) Compounds. J. Alloys Compd. 2014, 603, 7-13. [CrossRef]

20. Sato, T.; Mochizuki, T.; Ikeda, K.; Honda, T.; Otomo, T.; Sagayama, H.; Yang, H.; Luo, W.; Lombardo, L.; Züttel, A.; et al. Crystal Structural Investigations for Understanding the Hydrogen Storage Properties of $\mathrm{YMgNi}_{4}-\mathrm{Based}_{\mathrm{Alloys}}$ ASC Omega 2020, 5, 31192-31198. [CrossRef]

21. Prigent, J.; Gupta, M. Ab initio study of the hydrogenation properties of Mg-based binary and ternary compounds $\mathrm{Mg} 2 \mathrm{X}(\mathrm{X}=\mathrm{Ni}$, Si) and $\mathrm{YMgNi}_{4}$. J. Alloys Compd. 2007, 446-447, 90-95. [CrossRef]

22. Roquefere, J.-G.; Matar, S.F.; Bobet, J.-L. Stability of the hydrides $\mathrm{REMgNi}_{4} \mathrm{H}_{4}(\mathrm{RE}=\mathrm{Y}, \mathrm{Gd})$ from first principles. Int. J. Hydrog. Energy 2010, 35, 7858-7865. [CrossRef]

23. Guénée, L.; Favre-Nicolin, V.; Yvon, K. Synthesis, Crystal Structure and Hydrogenation Properties of the Ternary Compounds $\mathrm{LaNi}_{4} \mathrm{Mg}$ and $\mathrm{NdNi}_{4} \mathrm{Mg}$. J. Alloys Compd. 2003, 348, 129-137. [CrossRef]

24. Chotard, J.-N.; Sheptyakov, D.; Yvon, K. Hydrogen Induced Site Depopulation in the LaMgNi ${ }_{4}-$ Hydrogen System. Z. Kristallogr. 2008, 223, 690-696. [CrossRef]

25. Yang, T.; Yuan, Z.; Bu, W.; Jia, Z.; Qi, Y.; Zhang, Y. Effect of elemental substitution on the structure and hydrogen storage properties of $\mathrm{LaMgNi}_{4}$ alloy. Mater. Des. 2016, 93, 46-52. [CrossRef]

26. Sakaki, K.; Terashita, N.; Tsunokake, S.; Nakamura, Y.; Akiba, E. In Situ X-ray Diffraction Study of Phase Transformation of $\mathrm{Mg}_{2-\mathrm{x}} \mathrm{Pr}_{\mathrm{x}} \mathrm{Ni}_{4}$ during Hydrogenation and Dehydrogenation ( $\mathrm{x}=0.6$ and 1.0). J. Phys. Chem. C 2012, 116, 1401-1407. [CrossRef]

27. Sakaki, K.; Terashita, N.; Tsunokake, S.; Nakamura, Y.; Akiba, E. Effect of Rare Earth Elements and Alloy Composition on Hydrogenation Properties and Crystal Structures of Hydrides in $\mathrm{Mg}_{2-x} \mathrm{RE}_{\mathrm{x}} \mathrm{Ni}_{4}$. J. Phys. Chem. C 2012, 116, 19156-19163. [CrossRef]

28. Sakaki, K.; Terashita, N.; Kim, H.; Proffen, T.; Majzoub, E.H.; Tsunokake, S.; Nakamura, Y.; Akiba, E. Crystal Structure and Local Structure of $\mathrm{Mg}_{2-x} \mathrm{Pr}_{\mathrm{x}} \mathrm{Ni}_{4}$ ( $\mathrm{x}=0.6$ and 1.0) Deuteride Using in Situ Neutron Total Scattering. Inorg. Chem. 2013, 52, 7010-7019. [CrossRef]

29. Denys, R.V.; Riabov, A.B.; Černý, R.; Koval'chuk, I.V.; Zavaliy, I.Y. New $\mathrm{CeMgCo}_{4}$ and $\mathrm{Ce}_{2} \mathrm{MgCo}_{9}$ compounds: Hydrogenation properties and crystal structure of hydrides. J. Solid State Chem. 2012, 187, 1-6. [CrossRef]

30. Verbovytskyya, Y.; Opryska, V.; Paul-Boncourb, V.; Zavaliya, I.; Berezovetsa, V.; Lyutyya, P.; Kosarchyna, Y. Solid Gas and Electrochemical Hydrogenation of the Selected Alloys $\left(\mathrm{R}^{\prime}, \mathrm{R}^{\prime \prime}\right)_{2-\mathrm{x}} \mathrm{Mg}_{\mathrm{x}} \mathrm{Ni}_{4-\mathrm{y}} \mathrm{Co}_{\mathrm{y}}\left(\mathrm{R}^{\prime}, \mathrm{R}^{\prime \prime}=\mathrm{Pr}, \mathrm{Nd} ; \mathrm{x}=0.8-1.2 ; \mathrm{y}=0-2\right)$. J. Alloys Compd. 2021, 876, 160155. [CrossRef]

31. Shtender, V.V.; Denys, R.V.; Paul-Boncour, V.; Verbovytskyy, Y.V.; Zavaliy, I.Y. Effect of Co substitution on hydrogenation and magnetic properties of $\mathrm{NdMgNi}_{4}$ alloy. J. Alloys Compd. 2015, 639, 526-532. [CrossRef]

32. Shtender, V.V.; Denys, R.V.; Zavaliy, I.Y.; Zelinska, O.Y.; Paul-Boncour, V.; Pavlyuk, V.V. Phase equilibriain the Tb-Mg-Co system at $500{ }^{\circ} \mathrm{C}$, crystal structure and hydrogenation properties of selected compounds. J. Solid State Chem. 2015, 232, 228-235. [CrossRef]

33. Shtender, V.V.; Paul-Boncour, V.; Denys, R.V.; Crivello, J.-C.; Zavaliy, I.Y. TbMgNi ${ }_{4-\mathrm{x}} \mathrm{Co}_{\mathrm{x}}-(\mathrm{H}, \mathrm{D})_{2}$ System. I: Synthesis, Hydrogenation Properties, and Crystal and Electronic Structures. J. Phys. Chem. C 2020, 124, 196-204. [CrossRef]

34. Slater, J.C. Atomic radii in crystal. J. Phys. Chem. 1964, 41, 3199-3204. [CrossRef]

35. Aoki, K.; Masumoto, T. Solid State Amorphization of Intermetallic Compounds by Hydrogenation. J. Alloys Compd. 1993, 194, 251-261. [CrossRef]

36. Aoki, K.; Li, X.-G.; Masumoto, T. Differential thermal analysis of hydrogen-induced amorphization in C15 Laves phase GdFe 2 . Acta Metall. Mater. 1992, 40, 221-227. [CrossRef]

37. Ibarra, M.R.; del Moral, A. Magnetostriction and thermal expansion in rare earth- $\mathrm{Ni}_{2}$ intermetallic compounds. Proc-Int. Conf. Magn. Rare-Earths Actin. 1983, 1, 92-95.

38. Switendick, A.C. Band Structure Calculations for Metal Hydrogen Systems. Z. Phys. Chem. 1979, 117, 89-112. [CrossRef]

39. Borgschulte, A.; Terreni, J.; Billeter, E.; Daemen, L.; Cheng, Y.; Pandey, A.; Łodziana, Z.; Hemley, R.J.; Ramirez-Cuesta, A.J. Inelastic Neutron Scattering Evidence for Anomalous H-H Distances in Metal Hydrides. Proc. Natl. Acad. Sci. USA 2020, 117, 4021-4026. [CrossRef]

40. Yartys, V.A.; Denys, R.D.; Hauback, B.C.; Fjellvåg, H.; Bulyk, I.I.; Riabov, A.B.; Kalychak, Y.M. Short hydrogen-hydrogen separations in novel intermetallic hydrides, $\mathrm{RE}_{3} \mathrm{Ni}_{3} \mathrm{In}_{3} \mathrm{D}_{4}(\mathrm{RE}=\mathrm{La}, \mathrm{Ce}$ and $\mathrm{Nd})$. J. Alloys Compd. 2002, 330-332, 132-140. [CrossRef]

41. Vajeeston, P.; Ravindran, P.; Vidya, R.; Kjekshus, A.; Fjellvåg, H.; Yartys, V.A. Short hydrogen-hydrogen separation in RNiInH 1.333 (R = La, Ce, Nd). Phys. Rev. B 2003, 67, 014101. [CrossRef] 